\title{
Effect of feeding tuna oil or soyabean oil as supplements to sows in late pregnancy on piglet tissue composition and viability
}

\author{
J. A. Rooke, I. M. Bland and S. A. Edwards \\ Animal Biology Division, SAC, Craibstone Estate, Aberdeen AB21 9YA, UK \\ (Received 1 October 1997 - Revised 3 March 1998 - Accepted 9 March 1998)
}

\begin{abstract}
To investigate whether long-chain $n-3$ polyunsaturated fatty acids could cross the porcine placenta in late pregnancy and alter neonatal piglet tissue composition, multiparous sows (seven per diet) were fed on diets containing a supplement $(30 \mathrm{~g} / \mathrm{kg})$ of either soyabean oil or tuna oil for the last $21 \mathrm{~d}$ of pregnancy and the first $7 \mathrm{~d}$ of lactation. The proportions of all fatty acids, except 18:1n-7, differed between diets: in particular, the tuna-oil-containing diet supplied more 22:6n-3 and less 18:2n-6 fatty acids than the soyabean-oil-containing diet. The proportions of $n-3$ fatty acids, particularly $22: 6 n-3$ (g/100 g total fatty acids) in sow plasma, colostrum and milk were increased and the proportion of 18:2n-6 was decreased by feeding tuna oil. Piglet tissue $n-3$ fatty acid proportions (particularly 22:6n-3), obtained shortly after birth, were increased in piglets born to tuna-oil-fed sows compared with progeny of soyabean-oil-fed sows. The increase in the proportion of $n-3$ fatty acids (g/100 g total fatty acids) in piglet tissues as a result of tuna-oil feeding, compared with soyabean-oil-feeding, was in the order plasma > liver $>$ erythrocytes $>$ spleen $>$ brain $>$ retina. Piglets born to tuna-oil-fed sows had a lower viability score at birth than the progeny of soyabean-oil-fed sows. The proportions of long-chain $n-3$ fatty acid in tissues of new-born piglets were increased by feeding tuna oil to the sow in late pregnancy; however no improvements in piglet viability were observed.
\end{abstract}

Pregnancy: Tuna oil: Tissue fatty acids: Pig

Nutrient requirements for pigs (Agricultural Research Council, 1981) give specific recommendations for the $n-6$ essential fatty acid requirements of growing pigs but give no specific requirements for pregnant and lactating sows. No recommendations are given for $n-3$ fatty acids for pigs in general. In human nutrition, a supply of long-chain $n-3$ polyunsaturated fatty acids is of particular importance in late pregnancy as it is in this period that tissue deposition in the brain and retina is most rapid; these organs contain high concentrations of the $n-3$ fatty acids (Makrides et al. 1994). Indeed, an inadequate supply of $n-3$ fatty acids has been implicated in impaired visual function and cognitive development in man and experimental animals (Uauy et al. 1992; Wainwright, 1992; Faldella et al. 1996). As the piglet also undergoes rapid deposition of brain tissue in late pregnancy (Passingham, 1985), there may be a need to supply long-chain $n-3$ fatty acids to the developing piglet in this period.

Perinatal mortality of piglets (Varley, 1995) is an important loss to the pig industry. Despite improvements in husbandry in recent years, mortality remains at about $10 \%$ and may be increasing. The increase may result from selection for lean carcass composition as Herpin et al. (1993) have shown that piglets from lean genotypes are physiologically less mature at birth. Since commercial pig diets are based on cereals which are deficient in long-chain $n-3$ fatty acids, a contributory factor to low piglet viability at birth may be an imbalance or deficiency of dietary longchain $n-3$ fatty acid supply to the pregnant sow. Several recent studies have indicated that transfer of fatty acids across the porcine placenta may be limited (Thulin et al. 1989; Ramsay et al. 1991; Ruwe et al. 1991) as indicated by the substantially lower concentrations of non-esterified fatty acids (NEFA) in fetal plasma compared with maternal plasma, and the lack of response in fetal NEFA to changes in maternal NEFA. Therefore it was the objective of the present study to establish, by feeding tuna oil in late pregnancy and thereby increasing long-chain $n-3$ fatty acid supply to the sow, whether the fatty acid composition of the piglets and their viability at birth could be changed.

\section{Materials and methods}

Animals

Fourteen pregnant multiparous sows (Large White $\times$ Landrace, Newsham Hybrid Pigs Ltd, Malton, North Yorkshire, 
UK) were used in the experiment. At the start of the experiment the sows weighed $255 \mathrm{~kg}$, had a mean backfat thickness of $26 \mathrm{~mm}$ at the $\mathrm{P} 2$ position and mean parity was 3.5. Before allocation to diets the sows had been mated with Large White boars, housed in straw-bedded accommodation and fed with $2.5 \mathrm{~kg}$ of a standard commercial pregnancy diet daily. At the start of the experiment the sows were between 90 and $94 \mathrm{~d}$ of gestation, calculated from the date of first service.

\section{Experimental design and diets}

The sows were allocated to experimental diets, as they became available, over a period of $17 \mathrm{~d}$ and entered the experiment in groups of two to four animals. The objectives of allocation were to achieve two groups of sows balanced first for backfat thickness, second for weight, and third for parity. One group of seven sows was allocated to a diet containing soyabean oil and the other seven sows to a diet containing tuna oil. Mean live weights (264 and 247 (SE 12-3) $\mathrm{kg}$ ), backfat thickness $(25.4$ and 25.6 (SE 2.52) $\mathrm{mm}$ ) and parities $(3 \cdot 4$ and $3 \cdot 6$, SE $0 \cdot 20)$ did not differ significantly at allocation between the soyabean and tuna oil groups.

Soyabean or tuna oils were added ( $30 \mathrm{~g} / \mathrm{kg}$ diet) to a basal diet containing $(\mathrm{g} / \mathrm{kg})$ : milled barley 600 , wheatfeed 188 , soyabean meal 135, fishmeal 52 and mineral and vitamin mix (Sowvite 110, Norvite Ltd, Insch, Grampian, UK) 25. The mineral and vitamin mix was fortified with $\alpha$-tocopherol acetate as an antioxidant. The expected nutrient analysis of the diet was ( $/ \mathrm{kg}$ fresh weight): $13.5 \mathrm{MJ}$ digestible energy, $180 \mathrm{~g}$ crude protein, $0.94 \mathrm{~g}$ lysine, $59 \mathrm{~g}$ oil and $200 \mathrm{mg}$ vitamin E. Soyabean oil was obtained from Harbro Farm Sales, Turriff, Grampian, UK and the tuna oil, which contained a high concentration of 22:6n-3, was Tuna Orbital Oil (Scotia Pharmaceuticals Ltd, Carlisle, Cumbria, UK). Batches of feed were prepared twice weekly by mixing the oil with the basal diet in a $50 \mathrm{~kg}$ capacity horizontal mixer. The feed was stored at room temperature in sealed plastic bags with air excluded. Sows were given $2.5 \mathrm{~kg}$ feed daily until parturition. The same diets were fed for the first week of lactation in accordance with a commercial scale such that intakes were equivalent to the maintenance level of feeding for the first $3 \mathrm{~d}$ post-partum $(2 \mathrm{~kg})$ and then increased by $0.5 \mathrm{~kg}$ daily.

\section{Experimental procedures}

Sows. Two blood samples were obtained from each sow by jugular venepuncture into an evacuated tube containing potassium EDTA (18 mg), once, when allocated to the diets and again, $1 \mathrm{~d}$ before farrowing. Plasma was prepared from blood samples by centrifugation at $2000 \mathrm{~g}$ for $20 \mathrm{~min}$ and stored at $-20^{\circ}$ until analysed.

The sows were transferred to farrowing crates several days before parturition. On day 113 of pregnancy the sows were injected intramuscularly with $2 \mathrm{ml}$ of a synthetic prostaglandin analogue (cloprostenol, $92 \mathrm{mg} / \mathrm{ml}$ : Planate, Coopers Animal Health, Crewe, Ches., UK) at about 11.00 hours to induce farrowing (see next paragraph). During farrowing a sample of colostrum was obtained by hand from each sow from several teats. At $7 \mathrm{~d}$ after farrowing, a milk sample was obtained after injection of oxytocin (10 IU/ml, $1 \mathrm{ml}$ intramuscularly; Intervet UK, Cambridge, Cambs., UK).

Farrowing and piglets. It was intended to attend farrowing of all sows. However, one sow (soyabean oil) completed farrowing less than $12 \mathrm{~h}$ after injection of prostaglandin and three sows (two soyabean oil and one tuna oil) began farrowing before complete observations could be obtained. Therefore complete data on piglet viability at farrowing was restricted to ten litters and on piglet tissue composition to thirteen litters.

As each piglet was born it was scored for heart rate at birth, onset of respiration and standing time according to Zaleski \& Hacker (1993; see Table 1), and the time the piglet took to reach the udder and suck successfully was recorded. After completion of farrowing (30 min after expulsion of the placenta) the weight and sex of each piglet was recorded. From each litter, four piglets, consisting of two pairs of low and high body weight and with contrasting viability scores within pairs were selected. Piglets were anaesthetized by intraperitoneal injection of sodium pentobarbitone $(200 \mathrm{mg} / \mathrm{ml}$, Euthatal, Rhone Merieux, Harlow, Essex, UK) and a blood sample obtained by cardiac puncture. The blood was collected into a tube containing potassium EDTA. The piglet was then immediately killed by an overdose of sodium pentobarbitone. The brain, liver, spleen and eyes were removed and the weights of liver and brain recorded. The eyes were freed from connective tissue and the anterior half of the eyeball and contents of the eye removed. The posterior half of the eyeball and the liver, brain and spleen were stored at $-20^{\circ}$ until analysis. Plasma was prepared from the blood samples as described earlier and in addition blood cells were re-suspended three times and re-centrifuged in saline ( $9 \mathrm{~g} \mathrm{NaCl} / 1, \mathrm{pH} 7 \cdot 4$ containing $3 \mathrm{mM}-\mathrm{EDTA})$ and erythrocytes recovered and stored at $-20^{\circ}$.

Analytical procedures. Feed samples were analysed for $\operatorname{DM}\left(80^{\circ}\right.$ for $\left.18 \mathrm{~h}\right)$, ash $\left(550^{\circ}\right.$ for $\left.18 \mathrm{~h}\right)$, crude protein by the

Table 1. Calculation of piglet viability score* (Adapted from Zaleski \& Hacker, 1993)

\begin{tabular}{lcll}
\hline & \multicolumn{3}{c}{ Score } \\
\cline { 2 - 4 } Component & 0 & \multicolumn{1}{c}{1} & \multicolumn{1}{c}{2} \\
\hline Heart rate & Absent & $<120$ beats $/$ min & $>120$ beats $/$ min \\
Onset of breathing & Absent & $>15 \mathrm{~s}$ & $<15 \mathrm{~s}$ \\
First attempt to stand & $>5$ min & $1-5$ min & $<1$ min \\
\hline
\end{tabular}

* Heart rate and onset of breathing were measured immediately after each piglet was born. Total score was the sum of the three components. 
Kjeldahl method and acid ether extract and neutraldetergent fibre according to Ministry of Agriculture, Fisheries and Food (1992). The estimated digestible energy concentrations of the diets were also calculated according to Ministry of Agriculture, Fisheries and Food (1993).

Portions of feed or tissue samples were homogenized in a suitable excess of chloroform-methanol $(2: 1, \mathrm{v} / \mathrm{v})$ containing pentadecaenoic acid (15:0) as internal standard and extracts of total lipid in chloroform were prepared. Samples of the posterior half of the eyeball were vigorously mixed with saline $(0.9 \mathrm{~g} \mathrm{NaCl} / \mathrm{l})$ to remove the retinal cells from connective tissue before the retinal cells were extracted. Fatty acid methyl esters were prepared by transmethylation by refluxing the lipid in methanol-toluene-sulfuric acid (20:10:1, by vol.) for $30 \mathrm{~min}$. The fatty acid methyl esters were extracted into hexane before chromatography. Fatty acid methyl esters were separated by GLC using a capillary column (HP225, $30 \mathrm{~m} \times 0.25 \mathrm{~mm}$, film thickness $0.25 \mu \mathrm{m}$; Hewlett-Packard Ltd, Stockport, Ches., UK) in a Phillips PU4500 chromatograph. Peak identities were verified by comparison with the retention times of standard fatty acid methyl esters (Sigma Chemical Co. Ltd, Poole, Dorset, UK). Peak areas were determined with the aid of a Kontron DS450 Data System, Kontron Instruments, Watford, Herts., UK) and quantified using reference to the internal standard and a known standard (Supelco 37 Component mix, Supelco, Poole, Dorset, UK).

Plasma glucose and NEFA concentrations were determined by autoanalyser techniques. Glucose was determined enzymically using glucose oxidase ( $E C$ 1.1.3.4; Trinder, 1969) and NEFA by the enzymic production of $\mathrm{H}_{2} \mathrm{O}_{2}$ from acyl-CoA (Wako Chemicals, Neuss, Germany, method no. 994-75409).

\section{Statistics}

Data were analysed by ANOVA techniques using Genstat (Lawes Agricultural Trust, 1987). Where sampling was repeated (sow blood samples) or measurements were made on several animals (four piglets per litter), a split plot ANOVA was used with sow as the main plot and sampling time or piglet as the split plot. For data where the number of observations varied because of differences in litter size (viability data), a split plot ANOVA was carried out using the REML procedure of Genstat and diet effects assessed from Wald statistics and $\chi^{2}$ tests.

\section{Results}

\section{Diet}

The diets fed did not differ in proximate composition. Mean values (n 3) for the soyabean- and tuna-oil diets were respectively: DM (g/kg) 879 and 878 (SED 1.1); ash $(\mathrm{g} / \mathrm{kg}$ DM) 63 and 61 (SED 1.1); crude protein (g/kg DM), 213 and 206 (SED 13.4); acid ether extract (g/kg DM), 88 and 90 (SED 1.1); neutral-detergent fibre, 178 and 179 (SED 2.9) and calculated digestible energy (MJ/kg DM), $16 \cdot 0$ and $16 \cdot 0$ (SED 0.06).

As intended, adding either soyabean or tuna oil to the basal diet changed the profile of the fatty acids fed to the sows (Table 2). The most marked differences were increases in the proportions of $16: 0$ and 22:6n-3 and a decrease in the proportion of 18:2n-6 fatty acids (all $P<$ $0 \cdot 001)$ when tuna oil was included in the diet. As a result the tuna-oil diet contained more saturated fatty acids $(P<$ $0 \cdot 001)$ and a lower $n-6: n-3$ long-chain fatty acid ratio $(P<$ $0 \cdot 01)$ than the soyabean-oil-containing diet.

\section{Sow measurements}

Glucose (3.7-4.7 (SED 0.25) mmol/1, $n$ 7) and NEFA (0.08$0 \cdot 25(\operatorname{SED} 0 \cdot 065) \mathrm{mmol} / \mathrm{l}, n$ 7) concentrations in sow plasma increased $(P<0.05)$ between the start of the experiment $(92$ $\mathrm{d}$ of gestation) and the day on which farrowing was induced (day 113); the treatments imposed had no effect on these measurements. There were also changes in the proportions of fatty acids in sow plasma relating both to sampling time and diet (Table 2). Fatty acid profiles did not differ between groups at the start of the experiment. Independent of the type of oil fed, the proportions of saturated fatty acids increased $(P<0.01)$ and monounsaturated fatty acids decreased $(P<0 \cdot 01)$ between 92 and $113 \mathrm{~d}$ of gestation. Feeding tuna oil resulted in increases in the proportions of 20:5n-3 $(P<0.001)$ and 22:6n-3 $(P<0.01)$ and a decrease in the proportion of $18: 2 n-6(P<0.01)$ in sow plasma compared with soyabean oil. As a result, the proportion of total $n-3$ fatty acids increased $(P<0 \cdot 001)$ and the $n-6: n-3$ ratio decreased $(P<0 \cdot 001)$ when tuna oil was fed.

Feeding tuna and soyabean oils also changed the fatty acid profile of sow colostrum and milk ( $7 \mathrm{~d}$ post-partum). For both colostrum and milk, feeding tuna rather than soyabean oil (Table 3) decreased 18:2n-6 and increased 20:5n-3 and 22:6n-3 proportions $(P<0.001)$. As a result tuna-oil feeding reduced total $n-6$ fatty acids, increased $n-3$ fatty acids and reduced the $n-6: n-3$ fatty acid ratio in porcine milk and colostrum (all $P<0.001$ ). There were also differences, independent of diet, between milk and colostrum. Milk contained proportionately fewer saturated $(P<$ 0.001) (both 16:0 and 18:0) and 18:2n-6 fatty acids $(P<$ $0 \cdot 01)$ and more monounsaturated fatty acids $(P<0.001$; mainly $18: 1 n-9)$ than colostrum.

\section{Piglet measurements}

There were no differences in litter size or piglet weight as a result of feeding sows with different oils during late gestation. Therefore, mean total litter weights did not differ (soyabean, $17 \cdot 4 \mathrm{~kg}$; tuna $15 \cdot 3 \mathrm{~kg}$, SED $0 \cdot 87, n$ 7) between diets. The litters from which viability scores were calculated also did not differ in physical characteristics. The progeny of sows fed on soyabean oil had a significantly $(P<0.05)$ higher viability score $(4 \cdot 4 v \cdot 4 \cdot 1$, SED $0 \cdot 16, n 5)$, calculated as described in Table 1, than the progeny of tuna-oil-fed sows. There were no significant differences $(P>0.05)$ between piglets chosen for slaughter in plasma metabolites or organ weights (results not shown) although progeny of tuna-oil-fed sows had heavier brains (g/kg live weight; 24.5 v. $27 \cdot 0$, SED $1 \cdot 63, n 7)$.

The fatty acid profiles of piglet tissues sampled at 
Table 2. Fatty acid composition ( $\mathrm{g} / 100 \mathrm{~g}$ total fatty acids) of soyabean- and tuna-oil-containing diets fed to pregnant and lactating sows and of sow plasma before and after $21 \mathrm{~d}$ feeding diets containing soyabean or tuna oil in late gestation.

(Mean values with their standard errors)

\begin{tabular}{|c|c|c|c|c|c|c|c|c|c|c|c|}
\hline \multirow{2}{*}{ Fatty acid } & \multirow{2}{*}{\multicolumn{3}{|c|}{ Diet† }} & \multicolumn{8}{|c|}{ Sow plasma } \\
\hline & & & & Before & \multicolumn{2}{|c|}{$21 d$} & $\mathrm{SE} \S$ & SEll & \multicolumn{3}{|c|}{ Significance } \\
\hline $14: 0$ & 0.6 & 3.0 & $0 \cdot 10$ & 0.9 & 0.8 & 0.9 & 0.12 & 0.05 & NS & NS & * \\
\hline $16: 0$ & $14 \cdot 9$ & $20 \cdot 7$ & 0.31 & $17 \cdot 5$ & $16 \cdot 9$ & $18 \cdot 9$ & 0.12 & 0.20 & NS & NS & * \\
\hline $16: 1 n-7$ & 0.5 & $3 \cdot 3$ & 0.12 & $2 \cdot 3$ & $1 \cdot 2$ & $3 \cdot 0$ & 1.51 & 0.09 & NS & NS & NS \\
\hline $18: 1 n-7$ & $1 \cdot 3$ & $1 \cdot 8$ & 0.09 & $2 \cdot 7$ & $2 \cdot 3$ & $2 \cdot 3$ & 0.12 & $0 \cdot 10$ & NS & * & NS \\
\hline $18: 2 n-6$ & $51 \cdot 1$ & $22 \cdot 0$ & 0.42 & $31 \cdot 3$ & $33 \cdot 8$ & $21 \cdot 3$ & 3.62 & 0.85 & NS & * & ** \\
\hline $18: 3 n-3$ & $7 \cdot 2$ & $3 \cdot 0$ & 0.05 & $2 \cdot 0$ & $1 \cdot 7$ & $1 \cdot 0$ & 0.35 & 0.11 & NS & ** & * \\
\hline $20: 4 n-6$ & ND & 0.9 & - & $5 \cdot 4$ & $4 \cdot 9$ & $5 \cdot 6$ & 0.37 & 0.20 & NS & NS & NS \\
\hline $20: 5 n-3$ & 0.2 & 3.9 & $0 \cdot 16$ & $1 \cdot 6$ & 1.5 & $6 \cdot 2$ & 0.78 & 0.14 & ** & $* * *$ & $* * *$ \\
\hline $22: 5 n-3$ & ND & $1 \cdot 3$ & - & $1 \cdot 0$ & $1 \cdot 2$ & $0 \cdot 8$ & 0.19 & 0.03 & NS & NS & $\star *$ \\
\hline $22: 6 n-3$ & 0.4 & $17 \cdot 6$ & 0.39 & $2 \cdot 1$ & $2 \cdot 7$ & $8 \cdot 2$ & 0.59 & 0.40 & 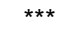 & $* *$ & ** \\
\hline$n-6: n-3$ & $6 \cdot 6$ & 0.9 & $0 \cdot 18$ & $5 \cdot 6$ & $5 \cdot 6$ & 1.9 & 0.31 & 0.29 & $* \star *$ & * & * \\
\hline
\end{tabular}

ND, none detected.

${ }^{*} P<0.05 ;{ }^{* *} P<0.01,{ }^{* \star *} P<0.001$

†For composition of diets, see p. 274. All comparisons between the compositions of the diets were significant $(P<0 \cdot 001)$ except for $18: 1 n-7(P<0.01)$ and total monounsaturated fatty acids $(P>0.05)$.

$\ddagger$ Three samples per diet.

§ For diet comparisons (seven samples per diet).

$\|$ For time and time $\times$ diet comparisons (seven samples per diet).

slaughter are given in Tables 4,5 and 6. Consistent differences in composition were observed as a result of feeding the two different oils to sows. The proportions of the longchain $n-3$ fatty acids, $20: 5 n-3$ and 22:6n-3, were increased in the progeny of tuna-oil-fed sows. These differences were significant for plasma, erythrocytes, liver and brain but smaller and non-significant for spleen and retina. As a consequence of increases in $n-3$ fatty acids there were decreases in other fatty acids as a result of tuna-oil feeding. In plasma and erythrocytes (Table 4) both monounsaturated (mainly 18:1n-9) and $n-6$ fatty acids (18:2 and 20:4) were reduced. In liver (Table 5), 18:1n-9 was reduced, with $n-6$ fatty acids largely unchanged. However in brain (Table 6), increases in the proportions of $n-3$ fatty acids were

Table 3. Fatty acid composition ( $\mathrm{g} / 100 \mathrm{~g}$ total fatty acids) of colostrum and milk ( $7 \mathrm{~d}$ post-partum) samples obtained from sows fed on soyabean- or tuna-oil-supplemented diets from 3 weeks pre-partum

(Mean values with their standard error)

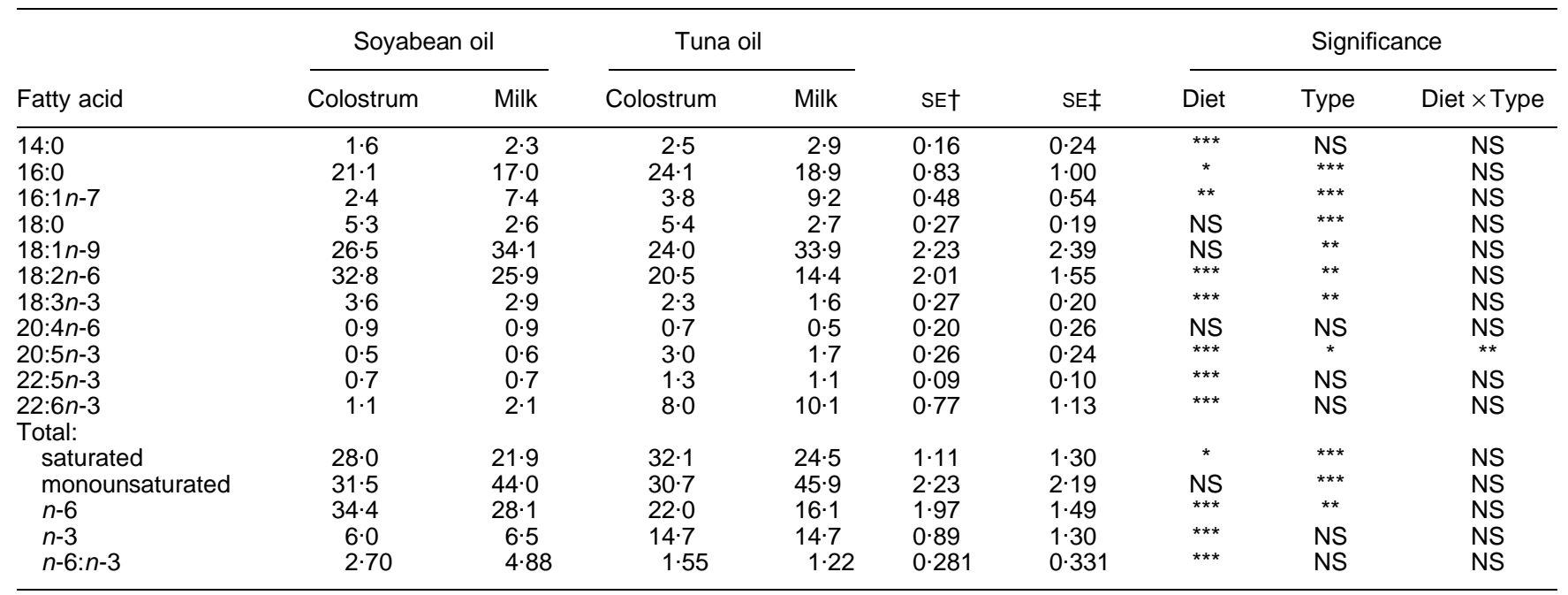

${ }^{*} P<0.05,{ }^{* *} P<0.01,{ }^{* * *} P<0.001$.

†For diet comparisons (seven observations per diet).

$\ddagger$ For type and type $\times$ diet interaction (seven observations per mean). 
Table 4. Fatty acid composition ( $\mathrm{g} / 100 \mathrm{~g}$ total fatty acids) of plasma and erythrocytes from piglets born to sows fed on either soyabean- or tuna-oil-containing diets from $21 \mathrm{~d}$ pre-partum

(Mean values are given for six (soyabean) and seven (tuna) observations, standard errors are given for seven observations)

\begin{tabular}{|c|c|c|c|c|c|c|}
\hline \multirow[b]{2}{*}{ Fatty acid } & \multicolumn{3}{|c|}{ Plasma } & \multicolumn{3}{|c|}{ Erythrocyte } \\
\hline & Soyabean & Tuna & SE & Soyabean & Tuna & SE \\
\hline $\begin{array}{l}14: 0 \\
16: 0 \\
16: 1 n-7 \\
18: 0 \\
18: 1 n-9 \\
18: 1 n-7 \\
18: 2 n-6 \\
20: 4 n-6 \\
20: 5 n-3 \\
22: 5 n-3 \\
22: 6 n-3\end{array}$ & $\begin{array}{r}1 \cdot 5 \\
23 \cdot 1 \\
4 \cdot 1 \\
12 \cdot 3 \\
23 \cdot 5 \\
5 \cdot 7 \\
12 \cdot 9 \\
7 \cdot 3 \\
1 \cdot 3 \\
\text { trace } \\
3 \cdot 6\end{array}$ & $\begin{array}{c}1 \cdot 8 \\
23 \cdot 2 \\
4 \cdot 2 \\
11 \cdot 1^{\star \star \star} \\
20 \cdot 9^{\star \star \star} \\
5 \cdot 0^{\star} \\
10 \cdot 0^{\star} \\
5 \cdot 7^{\star \star} \\
5 \cdot 2^{\star \star \star} \\
0 \cdot 4^{\star \star \star} \\
7 \cdot 7^{\star \star}\end{array}$ & $\begin{array}{l}0.54 \\
1.38 \\
0.51 \\
0.92 \\
0.82 \\
0.44 \\
1.75 \\
0.89 \\
0.50 \\
0.37 \\
0.97\end{array}$ & $\begin{array}{r}1 \cdot 3 \\
17 \cdot 5 \\
4 \cdot 1 \\
10 \cdot 1 \\
37 \cdot 0 \\
6 \cdot 3 \\
8 \cdot 7 \\
6 \cdot 5 \\
0 \cdot 4 \\
0 \cdot 4 \\
3 \cdot 8\end{array}$ & $\begin{array}{c}1 \cdot 1 \\
17 \cdot 4 \\
3 \cdot 9 \\
8 \cdot 3 \\
35 \cdot 6 \\
5 \cdot 7 \\
7 \cdot 7 \\
7 \cdot 0 \\
1 \cdot 8^{\star \star} \\
0 \cdot 8 \\
5.5\end{array}$ & $\begin{array}{l}0.40 \\
1.49 \\
0.22 \\
1.84 \\
1.89 \\
0.34 \\
0.67 \\
1.08 \\
0.51 \\
0.27 \\
1.07\end{array}$ \\
\hline \multicolumn{7}{|l|}{ Total: } \\
\hline $\begin{array}{l}\text { saturated } \\
\text { monounsaturated } \\
n-6 \\
n-3 \\
n-6: n-3\end{array}$ & $\begin{array}{c}37 \cdot 2 \\
37 \cdot 1 \\
20 \cdot 4 \\
5 \cdot 3 \\
4 \cdot 25\end{array}$ & $\begin{array}{l}36 \cdot 7^{\star \star} \\
33 \cdot 4^{\star \star} \\
16 \cdot 0^{\star \star \star} \\
13 \cdot 9^{\star \star \star} \\
1 \cdot 24^{\star \star \star}\end{array}$ & $\begin{array}{l}1 \cdot 80 \\
1.30 \\
1.42 \\
1 \cdot 60 \\
0.051\end{array}$ & $\begin{array}{c}29 \cdot 9 \\
48 \cdot 9 \\
16 \cdot 2 \\
4 \cdot 9 \\
3 \cdot 50\end{array}$ & $\begin{array}{l}27 \cdot 7 \\
47 \cdot 6 \\
15 \cdot 8^{\star \star} \\
8 \cdot 6^{\star \star} \\
1 \cdot 90^{\star \star \star}\end{array}$ & $\begin{array}{l}2 \cdot 99 \\
2 \cdot 12 \\
1.63 \\
1.79 \\
0.327\end{array}$ \\
\hline
\end{tabular}

Mean values were significantly different from those for the soyabean-oil diet: ${ }^{*} P<0.05,{ }^{* \star} P<0.01,{ }^{* * *} P<0.001$.

compensated almost entirely by decreases in the longchain $n-6$ fatty acids, 20:4 and 22:4. Only trace amounts of $18: 3 n-3$ fatty acid $(<0.5 \mathrm{~g} / 100 \mathrm{~g}$ total fatty acids) were detected in piglet tissues.

\section{Discussion}

The main objective of the present study was to establish whether feeding long-chain $n-3$ fatty acids from tuna oil to sows resulted in changes in piglet tissue fatty acid composition at birth. The diets fed changed the substrate supply both to the placenta and to the piglet. The concentrations of glucose and NEFA in sow plasma were higher immediately before parturition (113-114 d of gestation) than at the start of the experiment (90-94 $\mathrm{d}$ of gestation). Increases in plasma NEFA in late pregnancy have been observed in other studies (see Pere et al. 1997) and may represent mobilization of maternal fatty acids to meet the demands of rapid fetal growth in late pregnancy. The changes in sow plasma fatty acids between days 90 and 113 of gestation in general reflected the fatty acid composition of the diets fed. Thus, feeding tuna oil increased the $n-3$ polyunsaturated

Table 5. Fatty acid composition ( $\mathrm{g} / 100 \mathrm{~g}$ total fatty acids) of liver and spleen from piglets born to sows fed on either soyabean- or tuna-oil-containing diets from $21 \mathrm{~d}$ pre-partum

(Mean values are given for six (soyabean) and seven (tuna) observations; standard errors are given for seven observations)

\begin{tabular}{|c|c|c|c|c|c|c|}
\hline \multirow[b]{2}{*}{ Fatty acid } & \multicolumn{3}{|c|}{ Liver } & \multicolumn{3}{|c|}{ Spleen } \\
\hline & Soyabean & Tuna & SE & Soyabean & Tuna & SE \\
\hline $\begin{array}{l}14: 0 \\
16: 0 \\
16: 1 n-7 \\
18: 0 \\
18: 1 n-9 \\
18: 1 n-7 \\
18: 2 n-6 \\
20: 3 n-3 \\
20: 4 n-6 \\
20: 5 n-3 \\
22: 4 n-6 \\
22: 5 n-6 \\
22: 5 n-3 \\
22: 6 n-3\end{array}$ & $\begin{array}{r}2 \cdot 0 \\
15 \cdot 2 \\
6 \cdot 8 \\
9 \cdot 0 \\
24 \cdot 3 \\
7 \cdot 9 \\
10 \cdot 6 \\
0.9 \\
10 \cdot 5 \\
1 \cdot 8 \\
0 \cdot 3 \\
0 \cdot 6 \\
0 \cdot 6 \\
6 \cdot 6\end{array}$ & $\begin{array}{c}2 \cdot 1 \\
16 \cdot 3 \\
5 \cdot 8 \\
11 \cdot 6^{\star \star} \\
18 \cdot 7^{\star \star} \\
5 \cdot 4^{\star \star} \\
7 \cdot 1 \\
1 \cdot 1 \\
9 \cdot 2^{\star} \\
4 \cdot 1^{\star} \\
0 \cdot 5 \\
0 \cdot 7 \\
1 \cdot 8^{\star \star} \\
12 \cdot 9^{\star}\end{array}$ & $\begin{array}{l}0.50 \\
1.53 \\
1.07 \\
3.83 \\
2.33 \\
1.01 \\
2.31 \\
0.46 \\
1.89 \\
1.11 \\
0.20 \\
0.20 \\
0.49 \\
3.05\end{array}$ & $\begin{array}{r}5 \cdot 0 \\
16 \cdot 8 \\
2 \cdot 0 \\
9 \cdot 4 \\
17 \cdot 4 \\
6 \cdot 1 \\
8 \cdot 2 \\
2 \cdot 7 \\
19 \cdot 8 \\
2 \cdot 5 \\
2 \cdot 7 \\
1 \cdot 1 \\
2 \cdot 2 \\
6 \cdot 9\end{array}$ & $\begin{array}{c}7 \cdot 0 \\
14 \cdot 4 \\
2 \cdot 2 \\
6 \cdot 4^{\star} \\
19 \cdot 9^{\star \star} \\
6 \cdot 0 \\
8 \cdot 9 \\
3 \cdot 0 \\
19 \cdot 2 \\
3 \cdot 4 \\
2 \cdot 0^{\star} \\
1 \cdot 1 \\
2 \cdot 6 \\
8 \cdot 0\end{array}$ & $\begin{array}{l}0 \cdot 22 \\
2 \cdot 16 \\
0.25 \\
1.85 \\
0 \cdot 86 \\
0.45 \\
1.10 \\
0.92 \\
1.65 \\
0.85 \\
0.32 \\
0.24 \\
0.51 \\
0.68\end{array}$ \\
\hline $\begin{array}{l}\text { Total: } \\
\text { saturated } \\
\text { monounsaturated } \\
n-6 \\
n-3 \\
n-6: n-3\end{array}$ & $\begin{array}{c}26 \cdot 5 \\
40 \cdot 2 \\
22 \cdot 9 \\
9 \cdot 8 \\
2 \cdot 37\end{array}$ & $\begin{array}{l}30 \cdot 6^{\star \star} \\
30 \cdot 3^{\star \star} \\
19 \cdot 5^{\star} \\
18 \cdot 5^{\star} \\
1 \cdot 09^{\star \star}\end{array}$ & $\begin{array}{l}8 \cdot 34 \\
3 \cdot 72 \\
4.03 \\
4 \cdot 50 \\
0.487\end{array}$ & $\begin{array}{c}27 \cdot 1 \\
25 \cdot 9 \\
32 \cdot 2 \\
14 \cdot 4 \\
2 \cdot 51\end{array}$ & $\begin{array}{l}21 \cdot 9 \\
28 \cdot 7^{\star} \\
32 \cdot 7 \\
16 \cdot 3 \\
2 \cdot 27\end{array}$ & $\begin{array}{l}4 \cdot 00 \\
1 \cdot 47 \\
2 \cdot 26 \\
2 \cdot 41 \\
0 \cdot 364\end{array}$ \\
\hline
\end{tabular}

Mean values were significantly different from those for the soyabean-oil diet: ${ }^{*} P<0.05$, ${ }^{* *} P<0.01$. 
Table 6. Fatty acid composition ( $\mathrm{g} / 100 \mathrm{~g}$ total fatty acids) of brain and retina of piglets born to sows fed on either soyabean- or tuna-oil-containing diets from $21 \mathrm{~d}$ pre-partum

(Mean values are given for six (soyabean) and seven (tuna) observations; standard errors are given for seven observations)

\begin{tabular}{|c|c|c|c|c|c|c|}
\hline \multirow[b]{2}{*}{ Fatty acid } & \multicolumn{3}{|c|}{ Brain } & \multicolumn{3}{|c|}{ Retina } \\
\hline & Soyabean & Tuna & SE & Soyabean & Tuna & SE \\
\hline $14: 0$ & $1 \cdot 1$ & $1 \cdot 1$ & 0.08 & 0.7 & $1 \cdot 0$ & 0.42 \\
\hline $16: 0$ & $24 \cdot 7$ & $25 \cdot 2$ & 0.53 & $16 \cdot 4$ & $17 \cdot 6$ & 0.78 \\
\hline $16: 1 n-7$ & 1.3 & $1 \cdot 5^{\star \star}$ & 0.09 & $2 \cdot 1$ & $2 \cdot 1$ & $0 \cdot 12$ \\
\hline $18: 0$ & $20 \cdot 9$ & $20 \cdot 8$ & 0.43 & $12 \cdot 4$ & $12 \cdot 4$ & 0.79 \\
\hline $18: 1 n-9$ & $12 \cdot 7$ & $13 \cdot 0$ & 0.83 & $18 \cdot 3$ & $19 \cdot 0$ & 1.39 \\
\hline $18: 1 n-7$ & $4 \cdot 6$ & $4 \cdot 5$ & $0 \cdot 12$ & $5 \cdot 5$ & $5 \cdot 3$ & $0 \cdot 13$ \\
\hline $18: 2 n-6$ & 0.6 & $0 \cdot 3^{\star \star}$ & $0 \cdot 13$ & $3 \cdot 6$ & $3 \cdot 3$ & 0.32 \\
\hline $20: 4 n-6$ & $12 \cdot 1$ & $10 \cdot 8^{\star *}$ & 0.42 & $14 \cdot 8$ & $13 \cdot 6$ & 0.75 \\
\hline $20: 5 n-3$ & trace & $0 \cdot 4^{\star \star \star}$ & 0.07 & 0.9 & $1 \cdot 4$ & 0.35 \\
\hline $22: 4 n-6$ & $4 \cdot 2$ & $3 \cdot 3^{\star \star \star \star}$ & 0.22 & $2 \cdot 3$ & $1 \cdot 9$ & 0.22 \\
\hline $22: 5 n-3$ & $0 . \overline{3}$ & $1 \cdot 0^{\star \star \star}$ & 0.11 & $1 \cdot 7$ & 1.5 & 0.21 \\
\hline $22: 6 n-3$ & $13 \cdot 1$ & $14 \cdot 8^{\star \star \star}$ & 0.46 & $18 \cdot 7$ & $18 \cdot 2$ & 1.44 \\
\hline \multicolumn{7}{|l|}{ Total: } \\
\hline saturated & $47 \cdot 1$ & $47 \cdot 3$ & 0.56 & $29 \cdot 7$ & $31 \cdot 3$ & $1 \cdot 38$ \\
\hline monounsaturated & $19 \cdot 0$ & $19 \cdot 2$ & 0.97 & $26 \cdot 1$ & $26 \cdot 5$ & $1 \cdot 43$ \\
\hline & $15 \cdot 3$ & $13 \cdot 0_{t \star \star \star \star *}$ & 0.67 & $20 \cdot 4$ & $18 \cdot 3$ & 0.88 \\
\hline$n-3$ & $17 \cdot 7$ & $19 \cdot 5^{\star \star \star \star \star \star \star \star \star ~}$ & 0.52 & $23 \cdot 7$ & $23 \cdot 2$ & $1 \cdot 49$ \\
\hline$n-6: n-3$ & $0 \cdot 86$ & $0.67^{\star \star \star}$ & 0.043 & $0 \cdot 87$ & 0.83 & 0.059 \\
\hline
\end{tabular}

Mean values were significantly different from those for the soyabean oil diet: ${ }^{* \star} P<0.01,{ }^{* \star} P<0.001$.

fatty acids, especially $20: 5$ and $22: 6$, primarily at the expense of 18:2n-6. The proportionate amounts of $n-3$ fatty acids presented to the placenta for potential transfer to piglets in utero were therefore increased by tuna-oil feeding and net amounts of $n-6$ fatty acids decreased, although there were no changes in the concentration of 20:4n-6 in sow plasma.

The fatty acid compositions of sow colostrum and milk observed in the present experiment were similar to other reports, with 16:0, 18:1 and 18:2n-6 fatty acids being present in highest proportion (Hrboticky et al. 1991; Fritsche et al. 1993b; Taugbol et al. 1993; Arbuckle et al. 1994; Le Dividich et al. 1994) although the absolute proportions varied, probably as a result of the diets fed to the sows. Feeding tuna oil increased the proportions of $n-3$ fatty acids in both sow colostrum and milk $(7 \mathrm{~d}$ postpartum). In contrast to sow plasma, the increases in $n-3$ fatty acid proportions were mainly in $22: 6 n-3$, reflecting either differential uptake of fatty acids by the mammary gland from plasma or synthesis of 22:6n-3 in the mammary gland. Fritsche et al. (1993b) and Taugbol et al. (1993) have also described increases in colostrum and milk $n$-3 fatty acids when feeding marine oils to sows although the extent of the changes depended on the type of oil fed.

\section{Tissue fatty acid composition}

Because of studies on piglet viability carried out immediately after birth, there was a variable but limited consumption of colostrum before tissue samples were obtained. There are several reasons to suggest that colostrum consumption had little or no effect on the composition of piglet tissue fatty acids. First, in a subsequent study (Rooke et al. 1998) in which colostrum consumption was prevented, similar changes in tissue composition were observed. Second, when birth order within a litter and time from sucking to slaughter, both of which would be indices of colostrum intake, were included as covariates in the
ANOVA of the effect of diet on tissue composition, these covariates were not significant. Third, the stomach and intestines of many piglets were empty at slaughter indicating little or no colostrum consumption. Finally, in those piglets which had consumed colostrum, the stomach contained substantial amounts of colostrum. Le Dividich et al. (1997) have recently shown that gastric emptying is probably the main factor limiting availability of colostral fat for deposition or oxidation. Therefore it would seem probable that colostral fatty acids contributed little to the diet-related changes in tissue fatty acid composition observed in the present experiment.

The piglet tissues chosen for analysis in the experiment were selected either because of the importance of $n-3$ fatty acids to their function (retina and brain) or to provide comparisons with other studies (liver, spleen, plasma and erythrocytes) in which piglet tissue composition had been reported. In general, tissue fatty acid compositions of brain (Purvis et al. 1982; Arbuckle et al. 1994), retina (Hrboticky et al. 1991), liver (Farnworth \& Kramer, 1989a), erythrocyte (Foote et al. 1990) and plasma (Farnworth \& Kramer, $1989 b$; Fritsche et al. 1993a,b) were similar to other reports on neonatal piglets.

There are few data available on the effect of feeding different fatty acids to sows in late pregnancy on piglet tissue composition. Farnworth \& Kramer $(1989 a, b)$ fed sows with tallow- or soyabean-oil-supplemented diets from day 57 of gestation. After $110 \mathrm{~d}$ of gestation these authors found that fetal fatty acid composition was relatively insensitive to maternal diet. Fritsche et al. (1993a,b) gave menhaden oil to sows in late gestation (from day 107) and throughout the lactating period and observed changes in piglet plasma fatty acid proportions similar to those observed in the current experiment. However, Fritsche et al. $(1993 a, b)$ could not distinguish between placental and colostral/milk transfer of fatty acids because of the nature of their experimental design. The present study 
showed changes in the fatty acid profile of piglet liver and brain as a result of maternal diet and therefore of placental transfer of fatty acids. This is in contrast to recent reports (Thulin et al. 1989; Ramsay et al. 1991; Ruwe et al. 1991) which concluded that there was little or no transfer of fatty acids across the porcine placenta in late pregnancy. With reference particularly to the $n-3$ fatty acids in the tuna oil fed in the present experiment, there are two possible explanations which may account in part for this discrepancy. The net amounts of fatty acids transferred may indeed be small, or selective transfer of fatty acids to the fetus may take place. Total carcass fatty acids were not measured in the current experiment. However, estimating litter 22:6n-3 deposition from the experimental data suggests that less than $0 \cdot 05$ of the $22: 6 n-3$ fed to the sow was deposited in fetal tissues. The low value for deposition of $22: 6 n-3$ in fetal tissues suggests the present observations are not inconsistent with the view expressed by Thulin et al. (1989), Ramsay et al. (1991) and Ruwe et al. (1991) that fatty acid transfer across the placenta is limited in late pregnancy.

In the current experiment, feeding increased amounts of $n-3$ fatty acids to the sow in late pregnancy had differential effects on the proportions of $n-3$ fatty acids in piglet tissue as measured by the ratio of $n-3$ fatty acids $(\mathrm{g} / 100 \mathrm{~g}$ fatty acids) in piglet tissues derived from tuna oil-fed sows to those of soyabean-oil-fed sows. The ratios were: plasma, 2.6; liver, 1.9 ; erythrocytes $1 \cdot 8$; spleen, $1 \cdot 2$; brain, $1 \cdot 1$ and retina $1 \cdot 0$. Brain and retina contained the highest concentrations of long-chain $n-3$ fatty acids, especially $22: 6 n-3$, of the tissues examined. Piglet brain grows rapidly in the last $30 \mathrm{~d}$ of pregnancy (Passingham, 1985). Therefore, the period when the experimental diets were given corresponded to the period when fetal demands for long-chain $n$-3 fatty acids were greatest. The small response of brain $22: 6 n-3$ to feeding tuna oil suggests that brain requirements for total or long-chain $n$-3 fatty acids may have been met almost entirely by the soyabean-oil-containing diet. No requirements for $n$-3 fatty acids are given by Agricultural Research Council (1981). For $n-6$ fatty acids a daily requirement of 15 g 18:2n-6 is given. In human diets an $n-6: n-3$ fatty acid ratio of 6:1 has been recommended (British Nutrition Foundation, 1992) which would give a daily requirement of 2-3 g n-3 fatty acids for pigs. The diets used in the current experiment supplied approximately $150 \mathrm{~g}$ total fatty acids daily, which equates to $75 \mathrm{~g} n-6$ and $12 \mathrm{~g} n-3$ fatty acids for the soyabean-oil diet and $36 \mathrm{~g} n-6$ and $39 \mathrm{~g} n-3$ fatty acids for the tuna-oil diet. These calculations would suggest first that fatty acid requirements of the sow were met by both diets and second, from the small response to tuna oil in piglet brain fatty acids, that the requirements of the piglet in utero were being substantially met by the soyabean-oil diet. More detailed dietary studies would be necessary to establish $n-3$ requirements of the pregnant sow and whether a pre-formed supply of long-chain $n-3$ fatty acids is required over and above that which can be synthesized from 18:3n-3 by maternal and fetal tissues.

\section{Piglet viability}

The scoring method of Zaleski \& Hacker (1993) was used to assess piglet viability. The method has also been used by
Herpin et al. (1996) who found that scores were positively correlated with survival until $10 \mathrm{~d}$ of age. The scoring system is strongly correlated with the degree of anoxia experienced by the piglet during parturition (Zaleski \& Hacker, 1993; Herpin et al. 1996). Piglets born to sows fed with soyabean oil had a significantly higher viability score in the present experiment than did piglets born to tunaoil-fed sows. Piglets were born at the same gestational age as the sows were induced to farrow on days 113 and 114 of gestation. Competition between long-chain $n-3$ fatty acids, particularly $20: 5 n-3$, and $20: 4 n-6$ for prostaglandin synthetase enzymes and the lower biological activity of eicosanoids synthesized from 20:5n-3 (Weber, 1990) are well documented and may be the mechanisms underlying the relationship between increased gestation length and $n-3$ fatty acid intake in man (Olsen et al. 1991, 1992) and in sows fed on a 22:6n-3-rich fishmeal (Edwards \& Pyke, 1997). Therefore, in the present experiment, feeding tuna oil might have increased natural gestation length in these sows. As a consequence, when sows were induced to farrow on days 113 and 114, the sows fed with soyabean oil may have been closer to their natural farrowing date than tuna-oil-fed sows. The higher viability score of the progeny of soyabeanoil-fed sows may have been related to this factor.

In summary, feeding a supplement of $n-3$ fatty acids in the form of tuna oil to sows in late pregnancy, increased the concentrations of long-chain $n-3$ polyunsaturated fatty acids in piglet tissues, demonstrating that $n-3$ fatty acids can cross the porcine placenta in late pregnancy. However, the minimum amounts of dietary $n-3$ fatty acids required for normal function remain to be determined.

\section{Acknowledgements}

We thank Maureen Slessor for the care of the pigs and Morag Ewen and Ian McKay for technical assistance. SAC receives financial support from the Scottish Office Agricultural, Environment and Fisheries Department. The authors are grateful to Scotia Pharmaceuticals for the gift of the tuna oil.

\section{References}

Agricultural Research Council (1981) The Nutrient Requirements of Pigs. Slough: Commonwealth Agricultural Bureaux.

Arbuckle LD, MacKinnon MJ \& Innis SM (1994) Formula 18:2 $(n-6)$ and 18:3(n-3) content and ratio influence long-chain polyunsaturated fatty acids in the developing piglet liver and central nervous system. Journal of Nutrition 124, 289-298.

British Nutrition Foundation (1992) Unsaturated Fatty AcidsNutritional and Physiological Significance. The Report of the British Nutrition Foundation Task Force. London: Chapman and Hall.

Edwards SA \& Pike I (1997) Effects of fishmeal on sow reproductive performance. Proceedings of the British Society of Animal Science 1997, p. 55. Penicuik: British Society of Animal Science.

Faldella G, Govoni M, Rosina A, Marchiani E, Salvioli GP, Biagi PL \& Spano C (1996) Visual evoked potentials and dietary long chain polyunsaturated fatty acids in preterm infants. Archives of Disease in Childhood 75, F108-F112.

Farnworth ER \& Kramer JKG (1989a) Changes in the lipid composition of the internal organs of fetal pigs fed different dietary fats. Canadian Journal of Animal Science 69, 441-448. 
Farnworth ER \& Kramer JKG (1989b) The effects of changing sow dietary fatty acids on fetal plasma acid patterns. Canadian Journal of Animal Science 69, 813-817.

Foote KD, Hrboticky N, MacKinnon MJ \& Innis SM (1990) Brain synaptosomal, liver, plasma, and red blood cell lipids in piglets fed exclusively on a vegetable-oil-containing formula with and without fish-oil supplements. American Journal of Clinical Nutrition 51, 1001-1006.

Fritsche KL, Alexander DW, Cassity NA \& Huang S-C (1993a) Maternally-supplied fish oil alters piglet immune cell fatty acid profile and eicosanoid production. Lipids 28, 677-682.

Fritsche KL, Huang S-C \& Cassity NA (1993b) Enrichment of omega-3 fatty acids in suckling pigs by maternal dietary fish oil supplementation. Journal of Animal Science 71, 1841-1847.

Herpin P, Le Dividich J \& Amaral N (1993) Effect of selection for lean tissue growth on body composition and physiological state of the pig at birth. Journal of Animal Science 71, 2645-2653.

Herpin P, Le Dividich J, Hulin JC, Fillaut M, De Marco F \& Bertin R (1996) Effects of the level of asphyxia during delivery on viability at birth and early postnatal vitality of newborn pigs. Journal of Animal Science 74, 2067-2075.

Hrboticky N, MacKinnon MJ \& Innis SM (1991) Retina fatty acid composition of piglets fed from birth with a linoleic acid-rich vegetable-oil formula for infants. American Journal of Clinical Nutrition 53, 483-490.

Lawes Agricultural Trust (1987) Genstat 5 Reference Manual,. Oxford: Clarendon Press.

Le Dividich J, Herpin P, Mourot J \& Colin A-P (1994) Effect of low fat colostrum on fat accretion and lipogenic enzyme activities in adipose tissue in the 1-day-old pig. Comparative Biochemistry and Physiology 108,A, 663-671.

Le Dividich J, Herpin P, Paul E \& Strullu F (1997) Effect of fat content of colostrum on voluntary colostrum intake and fat utilization in newborn pigs. Journal of Animal Science 75, 707-713.

Makrides M, Neumann M, Byard RW, Simmer K \& Gibson RA (1994) Fatty acid composition of brain, retina, and erythrocytes in breast- and formula-fed infants. American Journal of Clinical Nutrition 60, 189-194.

Ministry of Agriculture, Fisheries and Food (1992) Analysis of Agricultural Materials, 2nd ed., London: H.M. Stationery Office.

Ministry of Agriculture, Fisheries and Food (1993) Prediction of the Energy Value of Compound Feedingstuffs for Farm Animals, . London: MAFF Publications.

Olsen SF, Hansen HS, Sommer S, Jensen B, Sørensen TIA, Secher NJ \& Zachariassen P (1991) Gestational age in relation to marine $n,-3$ fatty acids in maternal erythrocytes: a study of women in the Faroe Islands and Denmark. American Journal of Obstetrics and Gynecology 164, 1203-1209.
Olsen SF, Sørensen JD, Secher NJ, Hedegaard M, Henriksen TB, Hansen HS \& Grant A (1992) Randomised controlled trial of effect of fish-oil supplementation on pregnancy duration. Lancet 339, 1003-1007.

Passingham RE (1985) Rates of brain development in mammals including man. Brain, Behaviour and Evolution 26, 167-175.

Pere M-C, Dourmad J-Y \& Etienne M (1997) Effect of number of pig embryos in the uterus on their survival and development and on maternal metabolism. Journal of Animal Science 75, 13371342.

Purvis JM, Clandinin MT \& Hacker RR (1982) Fatty acid accretion during perinatal brain growth in the pig. A model for fatty acid accretion in human brain. Comparative Biochemistry and Physiology 72B, 195-199.

Ramsay TG, Karousis J, White ME \& Wolverton CK (1991) Fatty acid metabolism by the porcine placenta. Journal of Animal Science 69, 3645-3654.

Rooke JA, Bland IM \& Edwards SA (1998) Effect of maternal fatty acid supply on umbilical cord and piglet tissue composition. Biochemical Society Transactions (In the Press).

Ruwe PJ, Wolverton CK, White ME \& Ramsay TG (1991) Effect of maternal fasting on fetal and placental lipid metabolism in swine. Journal of Animal Science 69, 1935-1944.

Taugbol O, Framstad T \& Saarem K (1993) Supplements of cod liver oil to lactating sows. Influence on milk fatty acid composition and growth performance of piglets. Journal of Veterinary Medicine A 40, 437-443.

Thulin AJ, Allee GL, Harmon DL \& Davis DL (1989) Uteroplacental transfer of octanoic, palmitic and linoleic acids during late gestation in gilts. Journal of Animal Science 67, 738-745.

Trinder P (1969) Determination of glucose in blood using glucose oxidase with an alternate hydrogen acceptor. Annals of Clinical Biochemistry 6, 24-30.

Uauy R, Birch E, Birch D \& Peirano P (1992) Visual and brain function measurements in studies of $n,-3$ fatty acids requirements. Journal of Pediatrics 120, S168-S180.

Varley M (1995) The Neonatal Pig. Development and Survival. ,Wallingford: CAB International.

Wainwright PE (1992) Do essential fatty acids play a role in brain and behavioral development? Neuroscience and Biobehavioral Reviews 16, 193-205.

Weber PC (1990) The modification of the arachidonic acid cascade by $n,-3$ fatty acids. In Advances in Prostaglandin, Thromboxane and Leukotriene Research, vol. 20, pp. 233-240. [B Samuelsson, S-E Dahlen, J Fritsch and P Hedquist, editors]. New York, NY: Raven Press.

Zaleski HM \& Hacker RR (1993) Comparison of viability scoring and blood gas analysis as measures of piglet viability. Canadian Journal of Animal Science 73, 649-653. 